\title{
The Communicative Functions and Structural Principles of the English Euphemisms
}

\author{
TAN Ming-xian \\ Huai Yin Normal University, Huai An, China
}

\begin{abstract}
In the communication course of the language, the people will meet the unpleasant or awkward things unavoidably, and the direct, clear language states undoubtedly offend others, which will influence relations between people. So people avoid saying those words concerned with unpleasantness, and avoid saying those words which even can damage mutual relation, damage personal image. They change to use some gilded word to express their ideas. Euphemism, bearing the important task of lubrication of society, then comes into being. Without euphemism, the world operation will stop because of friction; the world will be filled with hatred. This article pays attention to analyzing the three communicative functions and the two structural principles of the English euphemisms mainly from the theory of modern linguistics.
\end{abstract}

Keywords: euphemisms, communicative function, structural principle, diversity of euphemisms, correlation of euphemisms

\section{Introduction}

The word "euphemism" comes from a Greek word, "euphemism" ("eu-", good, "pheme, voice"), which means "to use words of good omen". Euphemism is the substitution of an inoffensive or pleasant expression for a more unpleasant one, or for a term that evokes more directly a distasteful or taboo subject.

The communication is the important means used by human beings to maintain social relationships. And euphemism is a universal phenomenon of human language using process. In communication, in order to avoid language too straightly stated and to avoid doing harm to the other side, people use euphemisms. Therefore, people use more courtesy when talking about those unpleasant or embarrassing things. The euphemisms in English have broader applications, so learning more euphemisms usage will be of great help to our master of English. This article mainly discusses the communicative functions and the structural principles of English euphemisms.

\section{The Communicative Functions of English Euphemisms}

\section{Avoidance of Taboo}

The taboo is the euphemism initial function. This can be seen from the origin of euphemism. Euphemism is used for a long time and it is closely linked with the linguistic taboos. Indeed, euphemism origins from the early

TAN Ming-xian, lecturer, M.A., School of Foreign Languages, Huai Yin Normal University. 
language taboo in human civilization. While evading and abandoning taboo words, people have to find other terms to fill the vacancy, so they created euphemism. Neaman and Silver (1983) pointed out, euphemism is undoubtedly the first theme of the religion. In ancient times, human beings could not understand certain natural phenomena and natural forces, and then they produced a kind of supernatural worship and fear. This led to the superstition, and then developed into Fetishism, later World Fetishism. Reverence psychology to god and ghost made their names as the first psychological taboo words, and those words that become their alternatives became the earliest euphemisms. This kind of avoidance of taboo is embodied roughly in two aspects.

\section{About Death and Diseases}

Like Chinese, English-speaking people avoid talking about the death directly. There are many substitutes to express the idea in a roundabout way, such as, to be at rest, to be called to God, the final departure, final sleep, happy land, to have found rest, to have gone to a better world, to kick off (a piece of American slang), to be no more, to close one's eyes, return to dust, be safe in Jesus`s arms, and so on. There are also some other euphemisms relevant to death, such as, mortuary, funeral parlor for dead house; memorial service for funeral. To those people who are ill, especially badly ill, people use heart trouble to replace heart disease, use problem skin to replace acne, use long illness or big $\mathrm{C}$ to replace cancer, and use to be a little confused, or insane to replace insanity, and use not all there, simple-minded, soft in the head, of unsound mind to replace mad, and so on.

\section{Birth and Sex}

In English, usually people do not want to mention bear, but use come into the world to take its place. If someone is born, people do not say be born, but use see the light of day to take its place. People do not say naked but use in his birthday suit to take its place, people do not say pregnancy but use anticipating, expecting, or full of heir to take its place; people use in one's birthday suit to take the place of naked, and so on.

On sex, there are also many euphemisms. Prostitutes are called street girls, working girls, business girls, streetwalkers, call girls, etc. People use go to bed with somebody to take the place of having sex, use trial marriage to take the place of free love, use getting into trouble or somebody has an accident to take the place of heavy with child before wedding, the facts of life to take the place of knowledge of sex, love child to take the place of illegitimate child or bastard, spouse equivalent to take the place of adultery, and so on.

\section{Expression of Politeness}

The second function of euphemisms is to avoid hurting the feelings of others. When people have to mention something unpleasant, they often choose euphemisms. Here are the main aspects:

Euphemisms about the old. There are a lot of euphemisms about the old in English. This reflects that the Westerners avoid being old as a taboo. Therefore, those words, like old and aged, are substituted by some pleasant ones, like senior, golden aged, getting on years, felling one's prime, and second childhood. Neaman and Silver (1983) state this phenomenon wittily that in modern American society, there are no people who are old. There are people who are seasoned and well preserved. The old are called elder statesmen; senior citizens at least, or just they are called evasively old age pensioners or OAPS. They are not old, but longer living. Someone is actually old and ailing like a candle guttering in the wind, but is beautified as golden years.

Euphemisms about the disabled and people of low social status. In English, varieties of disabled people can be called handicapped, inconvenienced, or invalid. The deaf are said to be slow of hearing; the blind are said 
to be visually retarded; the color blind are said to be of color deficient; the disabled students are said to be special students.

People also use some gilded words to moderate those low social positions, almost each of which has a sweet sounding form of address. For example, hairdressers are given status to beauticians or hairstylists; shoe rebuilders are given status to cobblers; building engineers are given status to janitors; garbage collectors are given status to sanitation engineers or garbologists; undertakers are given status to funeral directors; grief therapists, bootblacks are given status to footwear maintenance engineers; floor-sweepers are given status to custodian engineers; dustman are given status to street orderly; and butchers are given status to meat-cutters. People also address secretaries as administrative assistants, and address housewives as homemakers or domestic engineers.

\section{Concealment of Truth}

As is known to all, euphemisms are vague and abstract, so lots of people in Western countries, especially the politicians, always use euphemisms to conceal some serious social problems. In that way, they can disguise the truth and whitewash the reality. Here are some examples:

Euphemisms used to disguise social problems, like poverty and crime. People whose living standard is below the low-income level are called the underprivileged, the disadvantaged, or the lower income group; people who are heavily in poverty and debt are called the negative savers. It is true that the company dismisses some workers, but it is said that those workers are to lay off, to ease out, to give the walking ticket. An unemployed mother is called a welfare mother; people who live on dole or pension are called people who live on welfare benefits. Economic crisis is called recession or depression; prostitution is called social evil. Seeking one's own profit in public affairs is called irregularity. Bribery is called to oil.

Euphemisms to conceal the truth of those aggressive wars. Those aggressive wars are called international armed conflicts; air contact is called air support or air strike; under bomb is called nuclear device, invasion is called involvement, etc. At midnight on May 7, 1999, the Chinese embassy building was severely damaged. In various news conferences, the NATO's attack on the Chinese embassy area was repeated as a terrible and tragic mistake. And at the same time, words like sorry, terribly sorry, and sympathetic, are used frequently to conceal their crimes.

\section{Conclusion}

This article is trying to use the theory of modern linguistics to analyze the communicative functions and the structural principles of the English euphemisms. And it pointed out three communicative functions and two structural principles: diversity and correlation. Euphemisms have a very strong vitality, involved in many aspects. With the development of the society and the improvement of the language art, those old euphemisms are out of use while new euphemisms are created continually. And people will pay more attention to using euphemisms in communication. Consequently, learning and understanding English euphemisms is very helpful not only to our understanding of more English culture, but also to the improvement of our ability to use language and ability of communication. 


\section{References}

CHEN, Y. (2000). Sociolinguistics. Beijing: The Commercial Press.

DENG, Y. C. (1998). Language and culture. Beijing: Foreign Language Teaching and Research Press.

GU, J. Z. (2002). Language and culture (2nd ed.). Shanghai: Foreign Language Education Press.

HU, W. Z. (1998). Comparision of cultural custom in English and Chinese. Beijing: Foreign Language Teaching and Research Press.

LI, R. H. (1997). Research of English-Chinese comparision. Shanghai: Shanghai Foreign language Education Press.

LUO, C. P. (1950). Language and culture. Beijing: Beijing University Press.

Neaman, J. S., \& Silver, C. G. (1983). Kind words: A thesaurus of euphemisms. Beijing: World Publishing Corp.

WANG, F. X. (2004). Culture of English language. Beijing: Beijing University Press.

WANG, W. Y. (1998). Euphemisms. Beijing: Xinhua Press.

ZHANG, X. G. (2005). English rhetoric. Beijing: Tsinghua University Press. 